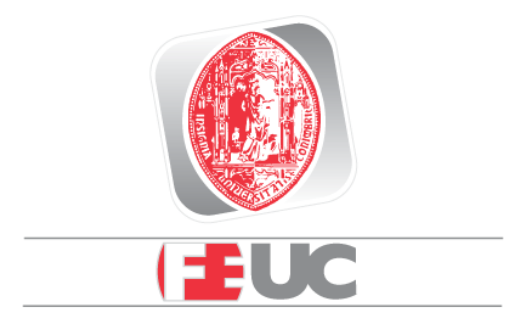

Faculdade de Economia Universidade de Coimbra

\section{Faculdade de Economia da Universidade de Coimbra}

Grupo de Estudos Monetários e Financeiros

(GEMF)

Av. Dias da Silva, 165 - 3004-512 COIMBRA, PORTUGAL

gemf@fe.uc.pt

http://gemf.fe.uc.pt

JOHN T. ADDISON \& PAULINO TEIXEIRA

The Effect of Works Councils on

Employment Change

ESTUDOS DO GEMF

N. ${ }^{\circ} 6$

2005

PUBLICAÇÃO CO-FINANCIADA PELA FUNDAÇÃO PARA A CIÊNCIA E TECNOLOGIA 


\title{
The Effect of Works Councils on Employment Change
}

Forthcoming in Industrial Relations

Institute of Industrial Relations, University of California, Berkeley.

\author{
John T. Addison* and Paulino Teixeira** \\ * Department of Economics, University of South Carolina, and Universidade de Coimbra \\ /GEMF (Portugal) \\ ** Faculdade de Economia, Universidade de Coimbra/GEMF (Portugal)
}

John T. Addison

Department of Economics

Moore School of Business

University of South Carolina

1705 College Street

Columbia, SC 29208

Tel.: 1 803-777-4608

Email: ecceaddi@moore.sc.edu

\author{
Paulino Teixeira \\ Faculdade de Economia \\ Universidade de Coimbra \\ Av. Dias da Silva, 165 \\ 3000 Coimbra \\ Portugal \\ Tel. (351) 239790565 \\ Email:Paulinot@fe.uc.pt
}

\footnotetext{
${ }^{\dagger}$ We thank, without implicating, David Blanchflower for his helpful comments on an earlier draft of this paper. We are also much indebted to one of the editors of this journal and two anonymous reviewers for their constructive suggestions.
} 


\title{
The Effect of Works Councils on Employment Change
}

\begin{abstract}
Despite recent changes in the relationship between unionism and various indicators of firm performance, there is one seeming constant in the Anglophone countries: unions at the workplace are associated with reduced employment growth of around $-2.5 \%$ a year. Using German data, we examine the impact of the works council - that country's form of workplace representation - on employment change, 1993-2001. The German institution appears to have much the same negative effect on employment growth. That said, survival bias seems to play a small role, and works councils do not seem to further slow the tortuous pace of employment adjustment in Germany.
\end{abstract}




\section{Introduction}

In an interesting analysis of the 1984 (1980) WIRS, Blanchflower, Millward, and Oswald (henceforth BMO) (1991) provided estimates of the union employment differential of $-3(-2.5)$ percentage points per annum. These first published estimates for Britain immediately attracted controversy. In particular, Machin and Wadhwani (1991) countered that there was no union effect per se, arguing that the reduced employment growth in unionized plants was only observed in those establishments that had experienced organizational change. Since they equated organizational change with the elimination of restrictive practices, it follows that Machin and Wadhwani saw something rather positive (however proximate) behind the negative association between union presence and employment growth, where observed. Their interpretation also contrasts with the conventional notion that worker representation has detrimental effects on the number of jobs via the union wage premium.

However, in the years following this localized debate the negative association between unions and employment found by $B M O$ (see also Blanchflower and Oswald, 1990) has become more rather than less entrenched. First of all, a number of British studies have confirmed the negative association between employment change and unionism (e.g. Fernie and Metcalf, 1995, using the 1990 WIRS; Addison and Belfield, 2001, using the 1998 WERS). More especially, Booth and McCulloch (1999) have reported that the union result is robust to the inclusion of an organizational change variable. Using the 1990 WIRS, these authors found that union recognition was associated with a 2.6 percent (5.7 percent) reduction in employment 1989-90 (1987-90). The constancy of the union employment effect stands out when compared with seeming 
shifts in union impact on other firm performance outcomes over the course of the 1980s and 1990s (see the review in Addison and Belfield, 2004). Indeed, for the 1990 WIRS, Blanchflower and Burgess (1996) also find that the union 'effect' (of some -2.0 percent per annum) also survives the incorporation of a variable capturing the introduction of new technology as well as changes in work organization, at least in plants employing at least 25 manual and non-manual employees.

Second of all, studies for other Anglophone countries have not only confirmed the inverse relationship between unions and employment growth but also reported similar point estimates. Thus, for example, in an analysis of the 1995 Australian Workplace Industrial Relations Survey, Wooden and Hawke (2000) reported that Australian unions slowed employment growth by approximately 2.5 percentage points a year. The North American evidence points in the same direction. Thus, in an investigation of some 1,800 Californian manufacturing plants, 1974-1980, Leonard (1992) reports that unionization reduced employment growth by between 2\% and 4\%. Similarly, Long’s (1993) analysis of a sample of 510 Canadian firms indicates that union firms grew a little under 4 percent less than their nonunionized counterparts between 1980 and $1985 .^{1}$

In this paper, we provide estimates of the employment effects of workplace representation in Germany. The dual system of industrial relations in that country means that our principal focus will be upon the impact of the works council (or Betriebsrat). The works council is the vehicle of employee representation at the workplace, while the focus of union activity is the industry-wide or regional collective agreement. However, we will also examine en passant whether or not the works council effect is sensitive to the plant being covered by an industry-wide collective agreement. It has been suggested 
in the German literature that other outcomes - in particular, labor productivity - are benefited in these circumstances. The argument is that where a works council is embedded in an external collective bargaining framework, the scope for the exertion of bargaining power at the workplace is narrowed and distributional conflict lessened, allowing the pro-productive aspects of works councils to come to the fore (Hübler and Jirjahn, 2003). While rent seeking on the part of the works council may be expected to limit employment growth, even in its absence delayed decision making associated with the information, consultation, and (above all) the codetermination rights of the works council in matters of labor allocation may have important negative effects on employment.

Germany is of particular interest for two main reasons. First, the Betriebsrat has long been looked upon with favor in European Union counsels, so that it has provided something of a template in the design of policies seeking to increase the involvement of European workers in their companies (see, for example, Official Journal, 2002). This policy interest is underscored by recent theoretical support for the German institution on collective voice/contract enforcement grounds (e.g. Freeman and Lazear, 1995). A second, narrower source of interest in the German situation is the availability of a unique data set - the Establishment Panel of the Institute of Labor Market Research of the Federal Labor Office (now Federal Labor Agency) - which among other things contains information on plant closings, allowing us to address the issue of possible selection bias in employment growth equations based on samples of survivors.

The plan of the paper is as follows. We first address the issue of model specification. Next, background information is provided on the works council institution 
as well as the longitudinal dataset. Results of fitting our employment change and dynamic labor demand equations are then presented. A brief summary concludes.

\section{Methodology}

The standard employment growth equation. Most British employment change analysis has been based on two cross-sections of establishment-level data, collected in, say, periods $t$ and $t-j$. Identification of the employment effect of worker representation (typically unionism, but in our case works councils) has been through an employment growth differential, which is the counterpart of the union wage differential in the much larger union wage literature.

Let us assume that employment level of establishment $i$ in period $t, l_{i t}$, is a function of works council status, economic conditions, and other establishment-specific variables. Then, denoting worker representation by $W_{0 c o_{i}}$ (a dichotomous variable assumed fixed between $t-j$ and $t$ ) and the other beginning-period establishment characteristics by $X_{i t-j}$, we have

$$
l_{i t}=\alpha_{o}+\lambda l_{i t-j}+\delta W_{o c o}+X_{i t-j} \beta+e_{i},
$$

where $\lambda(0<\lambda<1)$ indicates the degree of employment inertia over the $j$-year interval. In this framework, the long-run works council effect will be given by $\delta /(1-\lambda)$, obtained by setting $l_{i t}=l_{i t-j}$.

Empirical studies typically do not reject the null that $\lambda=1$, which result has led to the employment growth equation

$$
l_{i t}-l_{i t-j}=\alpha_{o}+\delta \mathrm{WoCO}_{i}+X_{i t-j} \beta+e_{i} .
$$


The works council employment growth differential is given by $\delta$. Identification of $\delta$ does rely in this case on a number of important restrictions. In particular, we assume exogenous switching between works council status, or a strongly ignorable treatment assignment (Manski, 1995, p. 42), according to which $\mathrm{P}\left(Y_{1} \mid X\right.$, Woco $\left.=1\right)=\mathrm{P}\left(Y_{1} \mid X\right.$, Woco $=0)$ (and $\mathrm{P}\left(Y_{0} \mid X\right.$, Woco $\left.=1\right)=\mathrm{P}\left(Y_{0} \mid X\right.$, Woco $\left.=0\right)$ ), where $Y_{1}$ is the outcome associated with works council presence and $Y_{0}$ is the outcome associated with 'no treatment' (i.e. no works council). We note that this assumption, while conventional, has not gone uncontested in the wider performance literature; see, in particular, Zwick's (2004) endogenous switching regression model of the productivity effects of management-led employee involvement on average productivity.

Using logs, the dependent variable in equation (2) is a proxy for the standard growth rate $g_{i} \equiv\left(l_{i t}-l_{i t-j}\right) / l_{i t-j}$. Alternatively, and in order to reduce the impact of outliers, employment changes can be computed using the formula $G_{i} \equiv\left(l_{i t}-l_{i t-j}\right) /\left[\left(l_{i t-j}+l_{i t}\right) / 2\right]$. In this case, the growth rate is symmetrical about zero and lies between -2 (for closings) and +2 (for openings). ${ }^{2}$

Survival bias. Implementation of model (2) is based on a sample of surviving establishments - in our case establishments observed in both 1993 and 2001. This raises a selection issue: if works councils increase the probability of workplace closure, any negative impact that they have on employment growth may be understated. BMO (1991, pp. 820-21) acknowledge that this 'survival bias' is a potentially serious lacuna of their analysis. Since we have information on closures, that is, on establishments that failed between $t-j$ and $t$, we are in a position to evaluate the presence of any such survival bias in OLS estimation of model (2). Formally, this amounts to investigating whether the 
unobserved determinants of establishment survival are correlated with the unobserved determinants of employment change. If the hypothesis of no correlation between the error terms in the two equations is rejected, then the works council effect estimated using the standard model will either over- or under-estimate the true effect on employment growth. For example, if the correlation is positive, then establishments more likely to fail will have lower employment growth; the marginal effect on employment growth of any common regressor in the two equations (the selection and outcome regressions) will then depend on the impact of that regressor on the probability of survival. In the case of the works council variable, a variable that may be presumed to explain both survival and employment growth, a positive correlation between error terms, combined with a negative impact of works council on survivability (see Addison, Bellmann, and Kölling, 2004), will yield a smaller employment reduction in the OLS estimation. The intuition in this case is that works councils contribute to the failure of establishments more prone to reduce employment.

More formally, and denoting the vector of all independent variables in model (2) by $\Omega$, the problem can be re-formulated as

$$
y_{i}=\Omega_{i} \omega+u_{1 i},
$$

where the employment growth variable $y_{i}$ is given either by $g_{i}$ or $G_{i}$. The outcome variable $y_{i}$ is observed if $T_{i}=1$ (i.e. where establishment $i$ is a survivor) and is not observed if $T_{i}=0$ (where establishment $i$ failed). In turn, survivability is a function of vector $W$ of explanatory variables as specified by the (latent) selection equation

$$
T_{i}^{*}=W_{i} \gamma+u_{2 i},
$$


where $T_{i}=1$ if $T_{i}^{*} \geq 0$ and $T_{i}=0$ if $T_{i}^{*}<0$. In this framework, it follows that $E\left(y_{i} \mid y_{i}\right.$ is observable $)$

$=\Omega_{i} \omega+E\left(u_{1 i} \mid T_{i}^{*} \geq 0\right)=\Omega_{i} \omega+E\left(u_{1 i} \mid u_{2 i} \geq-W_{i} \gamma\right)=\Omega_{i} \omega+\rho \sigma_{u 1}(\phi / \Phi)$,

where $\rho$ is the correlation between $u_{1}$ and $u_{2}, \phi$ is the standard normal density function, and $\Phi$ is the standard normal cumulative distribution function. Clearly, rejection of no correlation (namely, $\rho=0$ ) implies that $\omega_{O L S}$ is biased (and inconsistent). In other words, only by controlling for the correlation between $u_{1}$ and $u_{2}$ (the 'omitted' variable in the standard OLS estimation of model (3) using survivors) can one obtain the true effect of works council on employment growth. Expressed another way, OLS estimation of model (2) will only yield unbiased results under the assumption that uncensored (surviving) and censored (closings) units are equally affected by the presence of works councils.

Identification of the effect of works councils on employment using equations (3) and (4) relies on the assumption that there is an instrumental variable which explains selection (i.e. survivability) but not the outcome (employment growth) (see, for example, Manski, 1995, section 2.4). But note that in principle the selection model (3)-(4) is identified even if the set of variables in the selection and outcome equations are the same, but in this case identification is even more dependent on the specification of the model and its error structure being correct.

In our dataset there is no natural candidate (or candidates) to play the role of an instrumental variable, since the factors that influence survival should also influence employment growth (see Bryson, 2004). The problem is further compounded by the fact that not all conditioning variables are always observed, especially in the case of plants 
that subsequently fail. These circumstances make the selection of any instrumental variable more critical, resulting in an even higher risk of strong sensitivity of the findings to model specification than is typical in selection models. ${ }^{3}$

One response to these problems would be simply to assume exogenous selection, Rather than accept that no useful inference can be drawn in the presence of censoring, however, we adopt two approaches. The first, and preferred route, is to examine the potential influence of survival bias using a "commensurate” approach in which we assign to closings an employment change of -100 percent, as follows directly from the formula $g_{i} \equiv\left(l_{i t}-l_{i t-j}\right) / l_{i t-j}$ when establishment $i$ fails. ${ }^{4}$ Second, while conscious of ad hoc selection problems, we also present results using an instrumental variable. We sought to identify a survival equation using the proportion of workers employed under fixed term contracts. This argument has been found to explain plant closings in the German literature; it is furthermore not independently correlated with employment growth. We prefer the former procedure because its results are not conditional on specific distributional assumptions placed on survival. We offer the latter procedure more by way of a check.

Panel estimation. Our final approach is panel estimation that takes advantage of the longitudinal structure of a dataset. In this case, employment change is a one-year difference (the frequency of employment observation in the raw database is annual). The standard formulation of an employment adjustment specification in levels of the variables is then given $b y^{5}$

$$
l_{i t}=\lambda l_{i t-1}+\beta^{\prime}(L) X_{i t}+u_{i}+v_{t}+e_{i t},
$$


where $L$ is the lag operator, $\beta$ is the vector of coefficients of explanatory variables $X, u_{i}$ and $v_{t}$ represent unobserved firm- and time-specific effects, and $e_{i t}$ denotes the noise residual. The coefficient estimate of the key argument - the lagged employment term captures the degree of sluggishness in labor adjustment: the bigger the coefficient, the lower is the speed of employment adjustment to exogenous shocks.

OLS estimation of dynamic labor demand models (i.e. with a lagged dependent variable and firm-specific effects) upwardly biases the $\lambda$ parameter in model (5). ${ }^{6}$ Firstdifferencing the dynamic labor demand equation removes the individual effects $u_{i}$, but not the lagged (first-difference) employment term, which has to be instrumented using lagged levels of the variables. (Any non-strictly exogenous right-hand-side variable must also be instrumented using instruments in levels, while any strictly exogenous variable must be instrumented using lagged differences.) First-differences of model (5) and an instrumental variables method are therefore required. We will use in particular the linear estimator GMM-SYS developed by Blundell and Bond (1998), which is supposed to yield more precise parameter estimates and to reduce potentially important small sample bias stemming from the short sample periods of the typical panel.

To determine whether labor demand adjustment at micro level is sensitive to the presence of a works council we introduce the interaction term $\mathrm{Woco}_{i} * l_{i t-1}$ into equation (5). Allowing works council presence to affect employment inertia, thus gives

$$
l_{i t}=\lambda l_{i t-1}+\lambda_{1} \text { Woco }_{i} * l_{i t-1}+\beta^{\prime}(L) X_{i t}+u_{i}+v_{t}+e_{i t} .
$$

Under the hypothesis Ho: $\lambda_{1}=0$, employment inertia is given by $\lambda$. If Ho is rejected, then employment inertia is equal to $\left(\lambda+\lambda_{1}\right)$ if a works council is present. Clearly, works councils increase employment inertia if $\lambda_{1}>0$. We note that although an eight-year 
difference (between 1993 and 2001) is likely sufficient to produce statistical evidence of the effects of this type of worker representation on employment growth, a panel of nine annual observations is much less likely to reveal any corresponding impact on the speed of adjustment over the sample period, especially in circumstances where the employment inertia at establishment level is presumed to be very high anyway.

To avoid endogeneity problems, all units which have experienced a change in works council status were dropped from the sample (see footnote 9 below). It follows then that panel estimation of model (5) in first differences eliminates any time-invariant regressor, and therefore the panel employment growth differential associated with works councils cannot be estimated (by construction, $W \mathrm{coO}_{i}$ is fixed).

An alternative representation would be to include a time grouping dummy $d_{T}$, with $d_{T}=1$ if $t$ belongs to period $T, 0$ otherwise. In this case we have the model

$$
l_{i t}=\lambda l_{i t-1}+\beta^{\prime}(L) X_{i t}+\delta_{T} \text { Woco }_{i} * d_{T} * t+u_{i}+v_{t}+e_{i t} \text {. }
$$

Taking then first-differences will capture $\delta_{T}$, the employment growth differential between establishments with and without works councils in period $T .^{7}$ However, we do not have any priors as to how to form these time grouping dummies, $d_{T}$. And given the short length of the time-series on each unit there is moreover no natural grouping. The only other route would be to include the interaction term $W \mathrm{CoO}_{i} * t$, where $t$ represents a time trend, as follows

$$
l_{i t}=\lambda l_{i t-1}+\beta^{\prime}(L) X_{i t}+\delta_{1} W_{\text {oco }} * t+u_{i}+v_{t}+e_{i t} .
$$

First-differencing would then yield

$$
\Delta l_{i t}=\lambda \Delta l_{i t-1}+\beta^{\prime}(L) \Delta X_{i t}+\delta_{1} \text { Woco }_{i}+\Delta v_{t}+\Delta e_{i t} .
$$


In the findings section below, we will also provide evidence on the employment growth differential $\delta_{1}$ using the GMM-SYS estimator. ${ }^{8}$

\section{The Institution and the Dataset}

The Works Council. The German works council is mandatory but not automatic in all establishments with five or more employees. That is to say, the body has first to be elected: if workers in an establishment do not petition for a works council election, there will be no council, and if they do it is a fait accompli. As a practical matter, fewer than one-fifth of all plants with at least five employees have a works council, even if just over one-half of employees are covered by works councils (Addison, Bellmann, Schnabel, and Wagner, 2003).

The size of the works council is fixed by law and is a function of the establishment's employment level. More particularly, the information, consultation and codetermination rights of the council are also formally laid down under the law. Each is also a stepped function of establishment size. Thus, for example, we can with some justification speak of the formal powers of a council as being a datum between 21 and 100 employees. This particular size range is important in two respects. First, there is the general point that it makes sense to test for the impact of a works council by size categories within which the powers of the institution do not vary - in the absence of further information on works council heterogeneity. Second, and more narrowly, there is the point hinted at earlier that almost all large plants have a works council and small plants seldom do. For our sample in 2001, for example, 40 percent of establishments with 21-100 employees had works councils. In contrast, only 4 percent (no less than 94.5 
percent) of plants with less than 21 (more than 100) employees had work councils. Findings for the subsample of establishments with 21-100 employees therefore merit special attention.

The Dataset. Our data are taken from the Establishment Panel of the Institute for Employment Research of the Federal Labor Agency. Each year since 1993 (1996), this panel has surveyed several thousand establishments from all sectors of the economy in western (eastern) Germany. It is based on a stratified random sample - strata for 16 industries and 10 size classes - from the population of all establishments with at least one employee covered by social insurance. To correct for panel mortality, exits, and newlyfounded units, the data are augmented regularly, yielding an unbalanced panel. Data are collected in personal interviews with the owners or senior managers of the establishments by professional interviewers. The panel is created to serve the needs of the Federal Labor Agency, and so its focus is on employment-related matters. Further information on the panel - including information on the questionnaire(s) and how to access the data - are given in Kölling (2000).

Our inquiry uses information for the years 1993 to 2001, thus excluding eastern Germany in the interests of a longer panel of data. Note that some of the information related to year $t$ is asked for in the survey conducted in the following year. One such example is the value of sales in year $t$; as a result our demand data will be for seven rather than eight waves. In turn, information on works council status is available in 1993, 1996, 1998, 1999, 2000, and 2001 which requires some manipulation. In coding this key variable in the missing years, we assumed that the unobserved works council status of 
establishment $i$ in period $t$ was the same as that in period $t-1$ (or $t-2$ ) where there was no reported change between $t-1$ (or $t-2)$ and $t+1 .^{9}$

The full sample (i.e. establishments with at least 5 employees) in the beginning period (1993) comprises 786 continuing establishments (i.e. establishments both observed in 1993 and 2001). There are also 247 closures between 1993 and 2001, on which we have beginning-period (i.e. 1993) information on the relevant characteristics. (We will also have occasion to exploit information on those plants that exited the sample due to panel rotation. These attritions allow us to expand our sample of plants in the key 21-100 employee grouping.) Missing data on certain key variables in surviving establishments resulted in a further loss of some 190 observations. This problem is always confronted to a greater or lesser degree in longitudinal datasets, and in this case there was no discernible pattern in the missing data.

(Table 1 near here)

As shown in Table 1, employment growth across all establishments over the period 1993-2001 averaged -5.5 percent. This was the result of employment contraction of -11.6 percent a year in the slightly more than one-half of plants with works councils and very modest growth in employment of 2.6 percent a year in plants without works councils. The corresponding values for the subsample of plants with 21-100 employees were -4.0, -5.2, and -2.5 percent, respectively. These figures make the prima facie case for the proposition that work councils retard employment growth. Also shown in the table is the distribution of plants closings by works council status. For the entire sample, roughly 55 percent of the plant closings were in establishments with works councils. 
In addition to collecting data on employment, we also assembled information on workforce characteristics (namely, the percentage of part-time and female workers), establishment characteristics (the level of technology and dummies for single establishment entity and status as a publicly listed firm), and the average wage. This selection of these arguments was guided by their use in the literature and some need to maintain sample size. Thus, establishment size was included because prior (AngloSaxon) research has suggested that growth rates are lower in larger workplaces and firms - perhaps because the variable is an indicator of market power - even if survival prospects are increasing in size. Our plant technology measure is an index from 1 to 5 , where 1 represents state-of-the-art equipment and 5 denotes out-of-date equipment. It is expected that older technology will be associated with lower employment growth and possibly higher failure rates. Our two workforce characteristics variables are expected to reflect lower skill composition, and workforces that are perhaps more vulnerable to job loss on that account. Another justification for using the percentage of part-time workers reflects the fact that the employment size is not expressed in terms of full-time equivalents, even if this may pull in an opposite direction. (We note that the proportion of workers on fixed term contracts which variable is used to identify the plant survival equation - has a distinct rationale: such arrangements offer an indication of the scope to downsize as an alternative to closure. By the same token, the variable might also signal difficulties that lead to closure.). Workplaces belonging to larger organizations, may be expected to experience greater job turnover than single independent plants as the firm reallocates a given set of jobs between its establishments. We have no firm priors with respect to the other ownership argument: publicly listed firms may be positively 
associated with employment growth by reason of greater access to capital or they may record lower growth through incentives to restructure. For their part, higher wages might be expected to lower employment growth and not just employment levels where they are indicative of insider behavior. The above variables are supplemented with five, highly aggregative industry dummies. ${ }^{10}$

In addition to data on employment level and the gross wage, our dynamic labor demand model (see equations (5') and (7)) uses information on output demand, the prices of intermediate inputs, and capital. The latter argument requires some comment. Unlike the WIRS/WERS, the IAB Establishment Panel also contains information on the volume of capital investments (including 'expansion' or net investments), even if such data are missing for a large number of units. Since the expansion investment variable is only available from 1996 onward, we proxied annual changes in the capital stock by total capital investments. The measure does not therefore net out annual depreciation charges. Both it and all nominal variables were deflated by the GDP implicit price level, using OECD data.

\section{Findings}

The impact of works council presence on employment is presented in Tables 2 through 4. In each table, we consider results for the preferred subsample of establishments with 21-100 employees and for the full sample of all establishments with at least five employees.

Consider first implementation of the standard employment growth model, given by equation (2) (with $G_{i}$ as the dependent variable). As discussed earlier, this exercise 
uses two cross-sections to characterize employment growth over our eight-year period, 1993-2001. Employment growth is measured relative to average employment. The results are given in Table 2 and are quite striking. From the first column of the table we see that, other things being equal, works council plants grow approximately 16 percent less than their counterparts without works councils over the eight-year sample period. The other statistically significant covariates for the subsample are establishment size, the share of female workers, and (marginally) the wage. In contrast with some earlier findings for the Anglophone countries, the coefficient estimate for the employment-based establishment size variable is positive, although the directional influence of the two other arguments is as expected.

(Table 2 near here)

The second column of the table presents results for the whole sample. The negative works council effect is noticeably larger in absolute magnitude, although as was cautioned earlier the incidence of works councils is negligible in very small establishments (with less than 21 employees) and dominating in larger establishments (with more than 100 employees), so that in principle we prefer the results for the subsample, where there is a balanced representation of works councils and where additionally works council powers are datum (thus controlling in part for the heterogeneity of the institution). The directional influence of the other regressors is mostly the same as for the subsample. The main differences are that the wage coefficient estimate is better determined and the technology variable (but not the labor force composition arguments) achieves statistical significance at the .01 level. In addition, we 
note that publicly listed firms grow at a materially slower rate than their counterparts, while there was no indication of this in the subsample.

(Table 3 near here)

In Table 3 we add attritions associated with panel rotation to the sample. As can be seen, including attritions has a major effect on sample size. Two measures of employment growth are used. In the first and third columns of the table, employment change is simply that recorded over the life of the plant in the sample. The second and fourth columns convert the employment change into annual equivalents, now taking into account the number of years that the plant is in the panel. Otherwise, the measurement of employment change follows that of Table 2 which pertains to survivors alone. The main result of the increase in sample size is to increase the absolute magnitude of the works council effect - note that the point estimates in columns (2) and (4) may roughly be compared with one-eighth of the corresponding coefficients in Table 2. This increase in magnitude is somewhat more pronounced for the subsample. As far as the other arguments are concerned, the role of more advanced technology and one of the ownership variables in favoring employment growth is elevated in the subsample. For the full sample, the most notable result is the increase in precision with which the effects of the variables are estimated.

With the increase in sample size we are able to examine the effect of collective bargaining on the employment indicator. The results are remitted to Appendix Table 1. It will be recalled that some observers have claimed that where a works council is 'anchored' within an external collective bargaining agreement, any distributive effects of the institution may be secondary to its more integrative aspects. Assuming that 
distributive effects can be equated with reduced employment growth, we see that there are no overt signs of any such benefit of the dual system. The own-effect of works councils is reduced in absolute magnitude compared with the corresponding values in Table 3, but rather more to the point the collective agreement variable is statistically insignificant throughout and when interacted with the works council indicator is 'wrongly signed' and, in the case of the full sample, marginally significant as well.

(Table 4 near here)

We will return to the effects of collective bargaining below, but now turn to examine the vexed question of survival bias; in particular, the possibility that the negative employment effects of works councils may be understated in circumstances where work councils increase the probability of plant failure.

In Table 4 we provide the results of our two methods of correcting for potential survival bias. We need to preface these results by noting that our employment change variable differs from that used earlier. It is a now the simple percentage change in employment, 1993-2001, where the denominator is 1993 employment and not average employment as before. Our first approach for dealing with the potential problems raised by plant closings is to include them directly in the analysis by characterizing closures as representing a -100 percent change in employment. The results of this are provided in the second and fifth columns of the table for the subsample and full sample, respectively. Since we have not before presented results for the new measure of employment change, the relevant base equations are provided in the first and fourth columns of the table. Beginning with findings for our preferred subsample, it can be seen that the effect of including plant closings is to increase the absolute magnitude of the works council effect 
on employment by about one third. For the full sample the two point estimates are even closer together. In both cases there is overlap of the confidence intervals at conventional levels. From this perspective, we would conclude that failing to account for plant closings probably does not understate the negative effects of works councils on employment growth.

A parametric test for survival bias is contained in the third and sixth columns of Table 4. The framework is that of models (3) and (4). We assume here that the vector $W$ in the selection equation includes all observable characteristics relevant to survival, namely, works council status, wage level, establishment size, the shares of part-time and female workers, level of technology, and ownership status. All of these arguments enter the employment change equation. The only new and identifying variable is the share of fixed-term contract workers, an argument found in other (German) research to be positively associated with plant closings and here not (further) associated with employment change.

The third and sixth columns of Table 4 provide results for the selection and employment growth equations. It can be seen from the selection equation that although the direction of the effect of works councils on survival is negative, the point estimates are never statistically significant. The share of fixed-term contract workers is negatively associated with survival, suggesting that the variable flags hard times that lead to exit.

The selectivity-adjusted effects in the upper panel of the table fairly closely resemble those reported in columns (2) and (5). In particular, the works council effect is virtually unchanged. The more relevant comparison is, however, across columns (1) and (4). For neither the subsample nor the full sample does a likelihood ratio test reject the 
null ( $H_{O}: \rho=0$ ) of independence of the outcome and the selection models, implying that there is no reason for concern in providing OLS estimation of our employment change model. In other words, we do not have to be perturbed by the result that the correlation between the error terms in the employment growth and survival equations is negative, which would imply that the works council effect should be less negative (given the negative association between the entity and survival) and also raise a problem of economic interpretation because of the inference that the factors favoring survival are also those associated with slower growth.

As a final exercise, we reestimated the models in Table 4 with two additional controls: collective bargaining coverage and an interaction term between bargaining coverage and works council presence. The details are again consigned to an appendix. While there is some suggestion from Appendix Table 2 that collective bargaining coverage might benefit employment growth, the interaction terms are typically perverse. These observations pertain to the full sample. For the subsample, the inclusion of the two arguments leads to parameter instability without revealing anything about the impact of collective bargaining: both terms are statistically insignificant throughout.

We would tentatively conclude from both sets of evidence that the negative effects of work councils on employment in the standard OLS model are not upwardly biased. ${ }^{11}$ But that may be cold comfort as those effects are already sizeable.

We next turn to evidence based on our longitudinal panel, this time exploiting annual employment differences. The caveat in all of this is that past research points to very sluggish employment adjustment in Germany (e.g. Abraham and Houseman, 1994; Burgess, Knetter, and Michelacci, 2000). In other words, we anticipate that employment 
inertia will be high and therefore likely dominate the process of employment determination. Expressed in terms of models (5'), the parameter $\lambda$ should approach unity (and be highly statistically significant) while $\lambda_{1}$ should be close to zero (and perhaps insignificant).

(Table 5 near here)

The results in the first column of Table 5 confirm these expectations. As can be seen, the coefficient estimate of the lagged dependent variable is very large and close to unity, while the value of $\lambda_{1}$ is both small and statistically insignificant. Fitting the same model to data for the whole sample - in the third column of the table - produces virtually the same results.

The model also includes time dummies, to capture macroeconomic events specific to a given year, the input price of labor, the price of intermediate input, and a measure of the stock of capital. Firm-specific demand shocks (the shock variable) are proxied by (log) changes in establishment output demand. Regarding the regression diagnostic statistics, they nowhere point to any specification problems: the errors are, as expected, negatively first order serially correlated, with no evidence of second order serial correlation; the null of over-identifying restrictions is not rejected (the Sargan test); and the joint insignificance of the coefficients included in the regression is clearly rejected.

The selfsame panel framework also allows us to evaluate the association between works council presence and employment growth (the parameter $\delta_{1}$ in equation (7)) although, as we have cautioned, persistence in the employment data and our focus on annual changes may prove limiting in this regard. As can be seen from the second and fourth columns of the table, the direction of the works council effect is of the expected 
sign but the estimate is statistically insignificant. (As before, the respective regression statistics are within the expected range.) Evidently, in the German case the worker representation growth differential is best evaluated using a wider change interval than is permitted by dynamic analysis.

\section{Conclusions}

There is a remarkable convergence in the literature as to the effects of worker representation on employment change. The conclusion of BMO (1991) that worker representation - in their case, union coverage or density - costs job growth has stood the test of time. It has been replicated in subsequent studies for Britain and indeed for the Anglophone countries, where a central estimate is slowed employment growth in the order of 2.5 percent a year. The present exercise shows that this result seems also to hold for the very different institutional arrangements of Germany. Using data from two cross sections, we found that works councils were associated with reductions in employment growth of between 2 and 3 percent a year.

In a new departure, we also attempted to determine whether this central tendency was a lower bound estimate of the true effect of works councils, given some independent evidence that works councils are associated with higher rates of plant closure. We uncovered no real evidence of survival bias. This conclusion is necessarily tentative because of the difficulty of finding variables that are associated with employment growth but not plant closings, and the crudeness of the assumption that closing events and employment change are commensurate, respectively. In any event, the raw estimates of the employment reduction associated with works councils are substantial. 
In addition to exploring likely works council effects on employment growth using two cross sections of data, we more fully exploited the longitudinal nature of our dataset, using an employment adjustment specification in levels of variables. This approach yielded a negative association between the works council dummy and a time trend, consistent with the previous evidence. However, this growth effect was not statistically significant, reflecting the very high degree of employment inertia in the annual employment series. On the other hand, there was nothing in the data to suggest that works councils actually added to the sluggishness of the employment adjustment process in Germany.

We end on a conjecture. The negative effect of worker representation on employment in Germany as in other countries is consistent with classic insider behavior that may take companies to the brink if not lead them over the edge. Unfortunately, there is no suggestion that this insider behavior is attenuated by the dual system of industrial relations in Germany as analysts have claimed in investigating other performance outcomes. That is to say, the employment effects of works councils seem to be invariant with respect to collective bargaining regime. 


\section{REFERENCES}

Abraham, Katherine.G., and Susan N. Houseman. 1994. "Does Employment Protection Inhibit Labor Market Flexibility? Lessons from Germany, France and Belgium.” In Social Protection versus Economic Flexibility - Is There a Tradeoff? edited by Rebecca M. Blank, pp. 59-93. Chicago, IL: University of Chicago Press.

Addison, John T., and Clive R. Belfield. 2001. "Updating the Determinants of Firm Performance: Estimation Using the 1998 Workplace Employee Relations Survey.” British Journal of Industrial Relations 39 (September): 341-66.

Addison, John T., and Clive R. Belfield. 2004. "Unions and Establishment Performance: Evidence from the British Workplace Industrial/Employee Relations Surveys.” In The Changing Role of Unions: New Forms of Representation, edited by Phanindra V. Wunnava, pp. 281-319. Armonk, New York: M.E. Sharpe.

Addison, John T., Lutz Bellmann, Claus Schnabel, and Joachim Wagner. 2003. "German Works Councils Old and New: Incidence, Coverage, and Determinants." Schmollers Jahrbuch 123: 339-358.

Addison, John T., Lutz Bellmann, ans Arnd Kölling. 2004. "Works Councils and Plant Closings in Germany.” British Journal of Industrial Relations 42 (March): 12548.

Ahn, Hyungtaik, and James L. Powell. (1993). "Semiparametric Estimation of Censored Selection Models with a Nonparametric Selection Mechanism.” Journal of Econometrics 58 (July): 3-29.

Blanchflower, David G., and Simon M. Burgess. 1996. "New Technology and Jobs: Comparative Evidence from a Two Country study." Centre for Economic Performance Discussion Paper 1996-04, London School of Economics.

Blanchflower, David G. Neil Millward, and Andrew J. and Oswald, A.J. 1991. “Unionism and Employment Behavior.” Economic Journal 101 (July): 815-34.

Blanchflower, David G., and Andrew J. Oswald. 1990. "Unions and Jobs: Further Evidence.” Dartmouth College Working Paper.

Blundell, Richard, and Stephen R. Bond. 1998. "Initial Conditions and Moment Restrictions in Dynamic Panel Data Models.” Journal of Econometrics 87 (November): 115-43.

Booth, Alison L., and Andrew McCulloch. 1999. "Redundancy Pay, Unions, and Employment.” Manchester School. 67 (June): 346-66. 
Bound, John; David Jaeger, and Regina M. Baker. 1995. "Problems with Instrumental Variables Estimation When the Correlation between the Instruments and the Endogenous Explanatory Variable Is Weak.” Journal of the American Statistical Association 90 (June): 443-50.

Bryson, Alex. 2004. "Unions and Employment Growth in British Workplaces During the 1990s: A Panel Analysis.” Scottish Journal of Political Economy 51 (September): 477-506.

Burgess, Simon, Michael Knetter, and Claudio Michelacci. 2000. "Employment and Output Adjustment in the OECD: A Disaggregate Analysis of the Role of Job Security Provisions.” Economica 67 (August ): 419-35.

Davis, Steven J., John C. Haltiwanger, and Scott Schuh. Job Creation and Destruction. Cambridge, Mass: The MIT Press.

Fernie, Sue, and David Metcalf. 1995. "Participation, Contingent Pay, Representation and Workplace Performance: Evidence from Great Britain.” British Journal of Industrial Relations. 33 (September): 379-415.

Freeman, R.B. and Lazear, E.P. (1995), “An Economic Analysis of Works Councils.” In Works Councils: Consultation, Representation, and Cooperation in Industrial Relations, edited by Joel Rogers and Wolfgang Streeck, pp. 27-50. Chicago, IL: University of Chicago Press.

Hübler, Olaf, and Uwe Jirjahn. 2003. "Works Councils and Collective Bargaining in Germany: The Impact on Productivity and Wages.” Scottish Journal of Political Economy 50 (September): 571-91.

Kölling, Arnd. (2000). “The IAB Establishment Panel.” Schmollers Jahrbuch 120: 291300.

Leonard, Jonathan.S. (1992). "Unions and Employment Growth.” Industrial Relations, 31 (Winter): 80-94.

Long, Richard J. 1993. "The Impact of Unionization on Employment Growth of Canadian Companies.” Industrial and Labor Relations Review 46 (July): 691-701.

Machin, Stephen, and Sushil Wadhwani. 1991. "The Effects of Unions on Organizational Change and Employment.” Economic Journal 101 (July): 835-54.

Manski, Charles, F. 1995. Identification Problems in the Social Sciences. Cambridge, MA: Harvard University Press. 
Montgomery, Edward. 1989. "Employment and Unemployment Effects of Unions.” Journal of Labor Economics 7 (April): 170-90.

Newey, Whitney, K., James L. Powell, and James R. Walker. 1990. "Semiparametric Estimation of Selection Models: Some Empirical Results.” American Economic Review 80 (May): 324-28.

Nickell, Stephen J., Sushil Wadhwani, and Martin Wall. 1992. "Productivity Growth in United Kingdom Companies, 1975-1986.” European Economic Review 36 (June): 1055-85.

Official Journal. 2002. "Directive 2002/14/EC of the European Parliament and the Council of 11 March 2002 Establishing a General Framework for Informing and Consulting Employees in the European Community." Official Journal of the European Communities L 80 of 23.3.2003: 29-33.

Staiger, Douglas, and James H. Stock. 1997. "Instrumental Variables Regression with Weak Instruments.” Econometrica 65 (May): 557-86.

Wooden, Mark, and Anne Hawke. 2000. "Unions and Employment Growth: Panel Data Evidence.” Industrial Relations 39 (January): 88-107.

Zwick, Thomas. 2004. "Employee Participation and Productivity.” Labour Economics 11 (6): $715-40$. 


\section{Endnotes}

1. However, we should note that Blanchflower and Burgesss (1996) do not detect negative union employment growth effects using the 1990 Australian WIRS, while both North American studies referred to suggest that the union effect is concentrated among larger establishments/firms.

2. Omitting subscript $i$, the two growth rates are monotonically related by the formula $g=2 G /(2-G)$; see Davis, Haltiwanger, and Schuh (1996, p. 26).

3. Sensitivity of the results to the set of instrumental variables in selection models is widely documented; see, inter al., Ahn and Powell (1993), Bound, Jaeger, and Baker (1995), Newey, Powell, and Walker (1990), and Staiger and Stock (1997).

4. We are thankful to our editor for suggesting this approach.

5. Of course in this case the findings are only valid for surviving establishments.

6. An empirical illustration of this result in the context of labor demand can be found in Arellano and Bond (1991), and a formal proof of the bias in the OLS estimator is given by Hsiao (2003, pp. 73-74).

7. This particular approach is followed by Nickell, Wadhwani, and Wall (1992). First differences of model (6) would yield

$$
\Delta l_{i t}=\lambda \Delta l_{i t-1}+\beta^{\prime}(L) \Delta X_{i t}+\delta_{T} U_{i} * d_{T}+\Delta v_{t}+\Delta e_{i t} \text {. }
$$

8. Hsiao (2003, pp. 85-86) describes an instrumental variable procedure in which the coefficient estimate of any time-invariant regressor included in model (5) is estimated via OLS in a second and final step where the estimated $\lambda$ and $\beta$ are substituted into the initial model in levels. Since the information requirements associated with the required instrumental variables procedure - pertaining in particular to the number of cross-section units and the length of the time-series - are far from being met in our data set, we decided to stick with the GMM-SYS estimator, and rather provide evidence on the employment growth differential $\delta_{1}$ within the context of model specification (7).

9. Less than 2 percent of all establishments changed works council status over the eightyear interval. Accordingly, we chose to drop them from the sample.

10. Namely, manufacturing industries using mineral and other resources; manufacturing industries producing investment goods; manufacturing industries producing consumer goods plus construction; trade, transport, storage, and communications industries; and other services. The omitted category is the extractive industries. Agriculture, banking, and insurance were excluded from the sample. 
11. But for British evidence that accounting for sample selection may increase the absolute magnitude of the union effect on employment growth, see Bryson's (2004) analysis of the 1990-98 WIRS Panel. 
TABLE 1

EMPLOYMENT GROWTH RATES IN CONTINUING ESTABLISHMENTS AND PLANT CLOSINGS, 1993-2001, BY WORKS COUNCIL STSTUS AND ESTABLISHMENT SIZE

\begin{tabular}{|l|c|c|}
\hline \multirow{2}{*}{} & \multicolumn{2}{|c|}{ Establishment size } \\
\cline { 2 - 3 } & $21-100$ employees & $\begin{array}{c}\text { All establishments } \\
(\geq 5 \text { employees })\end{array}$ \\
\hline (a) Employment growth & $-5.2(\mathrm{n}=61)$ & $-11.6(\mathrm{n}=432)$ \\
\hline Works council establishments & $-2.5(\mathrm{n}=117)$ & $+2.6(\mathrm{n}=319)$ \\
\hline Non-works council establishments & $-4.0(\mathrm{n}=185)$ & $-5.5(\mathrm{n}=786)$ \\
\hline All establishments & & \\
\hline (b) Plant closings & $47 \%(\mathrm{n}=32)$ & $54 \%(\mathrm{n}=134)$ \\
\hline Works council establishments & $53 \%(\mathrm{n}=36)$ & $45 \%(\mathrm{n}=112)$ \\
\hline Non-works council establishments & $100 \%(\mathrm{n}=68)$ & $100 \%(\mathrm{n}=247)$ \\
\hline All establishments & & \\
\hline
\end{tabular}

Notes: The growth rate is given by the 8-year employment change $g_{i} \equiv\left(l_{i t}-l_{i t-j}\right) / l_{i t-j}$ (see text). 
TABLE 2

DETERMINANTS OF THE CHANGE IN EMPLOYMENT, 1993-2001

\begin{tabular}{|c|c|c|}
\hline \multirow[b]{2}{*}{ Variable } & \multicolumn{2}{|c|}{ Establishment size } \\
\hline & 21-100 employees & $\begin{array}{c}\text { All establishments } \\
\text { ( } \geq 5 \text { employees) }\end{array}$ \\
\hline Works council & $\begin{array}{l}-0.1581^{* * *} \\
(0.0551) \\
\end{array}$ & $\begin{array}{l}-0.2404^{* * *} \\
(0.0550) \\
\end{array}$ \\
\hline Wages & $\begin{array}{l}-0.1257^{*} \\
(0.0699) \\
\end{array}$ & $\begin{array}{l}-0.1445 * * * \\
(0.0450) \\
\end{array}$ \\
\hline Establishment size & $\begin{array}{l}0.5178 * * * \\
(0.0374)\end{array}$ & $\begin{array}{l}0.0921^{* * *} \\
(0.0149)\end{array}$ \\
\hline Share of part-time employees & $\begin{array}{c}0.2380 \\
(0.1614) \\
\end{array}$ & $\begin{array}{c}0.1297 \\
(0.1316) \\
\end{array}$ \\
\hline Share of female employees & $\begin{array}{l}-0.2773^{* *} \\
(0.1259)\end{array}$ & $\begin{array}{l}-0.1386 \\
(0.0898)\end{array}$ \\
\hline Index of technology & $\begin{array}{l}-0.0389 \\
(0.0296) \\
\end{array}$ & $\begin{array}{l}-0.0944^{* * *} \\
(0.0229) \\
\end{array}$ \\
\hline Single establishment firm & $\begin{array}{l}-0.0140 \\
(0.0564)\end{array}$ & $\begin{array}{c}0.0356 \\
(0.0403) \\
\end{array}$ \\
\hline Publicly listed firm & $\begin{array}{c}0.0599 \\
(0.1535)\end{array}$ & $\begin{array}{l}-0.1832 * * * \\
(0.0528)\end{array}$ \\
\hline Constant + industry dummies & Yes & Yes \\
\hline Adjusted $\mathrm{R}^{2}$ & 0.63 & 0.11 \\
\hline $\mathrm{F}$ & 19.20 & 6.83 \\
\hline $\mathrm{N}$ (surviving establishments) & 143 & 600 \\
\hline
\end{tabular}

Notes: The model specification is given by $G_{i}=\alpha_{o}+\delta W_{o c o}+X_{i t-j} \beta+e_{i}$, where $G_{i} \equiv\left(l_{i t}-l_{i t-j}\right) /\left(\left(l_{i t-j}+l_{i t}\right) / 2\right) . l_{i t}$ is the employment level of establishment $i$ in period $t ; X_{i t-j}$ denotes beginning-period (1993) establishment characteristics; and Woco is the works council status. The model is estimated by OLS. The sample was extracted from a raw sample of 771 continuing establishments with at least 5 employees. Standard errors are given in parenthesis; ${ }^{* * *},{ }^{* *}, *$ denote statistical significance at the $.01, .05$, and .10 levels, respectively. 
TABLE 3

DETERMINANTS OF THE CHANGE IN EMPLOYMENT, 1993-2001, WITH ATTRITIONS

\begin{tabular}{|c|c|c|c|c|}
\hline \multirow[b]{3}{*}{ Variable } & \multicolumn{4}{|c|}{ Establishment size } \\
\hline & \multicolumn{2}{|c|}{ 21-100 employees } & \multicolumn{2}{|c|}{$\begin{array}{l}\text { All establishments } \\
\text { ( } \geq 5 \text { employees) }\end{array}$} \\
\hline & $(1)$ & $(2)$ & (3) & $(4)$ \\
\hline Works council & $\begin{array}{l}-0.2115 * * * \\
(0.0522)\end{array}$ & $\begin{array}{l}-0.0320^{* * *} \\
(0.0091) \\
\end{array}$ & $\begin{array}{l}-0.2551 * * * \\
(0.0390)\end{array}$ & $\begin{array}{l}-0.0411 * * * \\
(0.0064)\end{array}$ \\
\hline Wage & $\begin{array}{l}-0.0611 \\
(0.0681)\end{array}$ & $\begin{array}{l}-0.0026 \\
(0.0119)\end{array}$ & $\begin{array}{l}-0.1386 * * * \\
(0.0348)\end{array}$ & $\begin{array}{l}-0.0202 * * * \\
(0.0057)\end{array}$ \\
\hline Establishment size & $\begin{array}{l}0.4091 * * * \\
(0.0384)\end{array}$ & $\begin{array}{l}0.0498 * * * \\
(0.0067)\end{array}$ & $\begin{array}{l}0.0952 * * * \\
(0.0107)\end{array}$ & $\begin{array}{l}0.0152 * * * \\
(0.0017)\end{array}$ \\
\hline Share of part-time employees & $\begin{array}{l}0.2385 \\
(0.1491)\end{array}$ & $\begin{array}{l}0.0210 \\
(0.0261)\end{array}$ & $\begin{array}{l}0.1686^{* * *} \\
(0.0962)\end{array}$ & $\begin{array}{l}0.0326 * * \\
(0.0158)\end{array}$ \\
\hline Share of female employees & $\begin{array}{l}-0.1746 \\
(0.1098)\end{array}$ & $\begin{array}{l}-0.0129 \\
(0.0192)\end{array}$ & $\begin{array}{l}-0.2002 * * * \\
(0.0632)\end{array}$ & $\begin{array}{l}-0.0315^{* * *} \\
(0.0104)\end{array}$ \\
\hline Index of technology & $\begin{array}{l}-0.0790 * * * \\
(0.0272)\end{array}$ & $\begin{array}{l}-0.0137 * * * \\
(0.0047)\end{array}$ & $\begin{array}{l}-0.0908 * * * \\
(0.0165)\end{array}$ & $\begin{array}{l}-0.0144 * * * \\
(0.0027)\end{array}$ \\
\hline Single establishment firm & $\begin{array}{c}0.0322 \\
(0.0538) \\
\end{array}$ & $\begin{array}{c}0.0065 \\
(0.0094) \\
\end{array}$ & $\begin{array}{c}0.0101 \\
(0.0280)\end{array}$ & $\begin{array}{l}0.0015 \\
(0.0046) \\
\end{array}$ \\
\hline Publicly listed firm & $\begin{array}{l}0.4014 * * * \\
(0.1215)\end{array}$ & $\begin{array}{l}0.0600 * * * \\
(0.0213)\end{array}$ & $\begin{array}{l}-0.1410 * * * \\
(0.0358)\end{array}$ & $\begin{array}{l}-0.0229 * * * \\
(0.0059)\end{array}$ \\
\hline Constant + industry dummies & Yes & Yes & & Yes \\
\hline Adjusted $\mathrm{R}^{2}$ & 0.39 & 0.24 & 0.15 & 0.14 \\
\hline $\mathrm{F}$ & 12.25 & 6.68 & 15.85 & 15.24 \\
\hline $\begin{array}{l}\text { N (surviving establishments, } \\
\text { plus attritions) }\end{array}$ & 232 & 232 & 1106 & 1106 \\
\hline
\end{tabular}

Notes: The sample includes establishments that exited the panel due to attrition. The dependent variable in columns (1) and (3) is given by the $j$-year difference $G_{i}$ (see Table 2). In columns (2) and (4), the dependent variable is the annualized growth rate obtained dividing $G_{i}$ by $j(j+1$ is the number of years an establishment is in the panel, $1 \leq j \leq 8$ ). 
TABLE 4

DETERMINANTS OF THE CHANGE IN EMPLOYMENT, 1993-200, CONTROLLING FOR POTENTIAL SURVIVAL BIAS

\begin{tabular}{|c|c|c|c|c|c|c|}
\hline & \multicolumn{6}{|c|}{ Establishment size } \\
\hline & \multicolumn{3}{|c|}{ 21-100 employees } & \multicolumn{3}{|c|}{$\begin{array}{c}\text { All establishments } \\
(\geq 5 \text { employees })\end{array}$} \\
\hline & \multirow[b]{2}{*}{$\begin{array}{l}\text { Unadjusted for } \\
\text { selection }\end{array}$} & \multicolumn{2}{|c|}{ Adjusted for selection } & \multirow{2}{*}{$\begin{array}{l}\text { Unadjusted } \\
\text { for selection }\end{array}$} & \multicolumn{2}{|c|}{ Adjusted for selection } \\
\hline & & $\begin{array}{c}\text { Closings }=- \\
100 \%\end{array}$ & $\begin{array}{l}\text { Full } \\
\text { maximum- } \\
\text { likelihood }\end{array}$ & & $\begin{array}{c}\text { Closings=- } \\
100 \%\end{array}$ & $\begin{array}{l}\text { Full maximum- } \\
\text { likelihood }\end{array}$ \\
\hline Change in employment & $(1)$ & $(2)$ & $(3)$ & $(4)$ & (5) & $(6)$ \\
\hline Works council & $\begin{array}{l}-0.1771 * * * \\
(0.0533)\end{array}$ & $\begin{array}{l}-0.2385 * * * \\
(0.0850)\end{array}$ & $\begin{array}{l}-0.2245 * * * \\
(0.0572)\end{array}$ & $\begin{array}{l}-0.2571^{* * *} \\
(0.0587)\end{array}$ & $\begin{array}{l}-0.2305^{* * *} \\
(0.0638)\end{array}$ & $\begin{array}{l}-0.2516^{* * *} \\
(0.0608)\end{array}$ \\
\hline Wage & $\begin{array}{l}-0.0751 \\
(0.0677) \\
\end{array}$ & $\begin{array}{l}-0.0329 \\
(0.1042) \\
\end{array}$ & $\begin{array}{l}-0.0483 \\
(0.0709)\end{array}$ & $\begin{array}{l}-0.1390 * * * \\
(0.0480)\end{array}$ & $\begin{array}{l}0.0230 * * * \\
(0.0508)\end{array}$ & $\begin{array}{l}-0.1826 * * * \\
(0.0506)\end{array}$ \\
\hline Establishment size & $\begin{array}{l}0.4510^{* * *} \\
(0.0362)\end{array}$ & $\begin{array}{l}0.3635^{* * *} \\
(0.0640)\end{array}$ & $\begin{array}{l}0.4937^{* * *} \\
(0.0399) \\
\end{array}$ & $\begin{array}{l}0.0837^{* * *} \\
(0.0159)\end{array}$ & $\begin{array}{l}0.1176 * * * \\
(0.0174) \\
\end{array}$ & $\begin{array}{l}0.0843^{* * *} \\
(0.0170) \\
\end{array}$ \\
\hline $\begin{array}{l}\text { Share of part-time } \\
\text { employees }\end{array}$ & $\begin{array}{l}0.4461 * * * \\
(0.1563)\end{array}$ & $\begin{array}{l}0.6893 * * * \\
(0.2610)\end{array}$ & $\begin{array}{l}0.2285 \\
(0.1674)\end{array}$ & $\begin{array}{c}0.3493^{*} \\
(0.1403)\end{array}$ & $\begin{array}{l}0.7048 * * * \\
(0.1472)\end{array}$ & $\begin{array}{l}0.3210^{* *} \\
(0.1501)\end{array}$ \\
\hline $\begin{array}{l}\text { Share of female } \\
\text { employees }\end{array}$ & $\begin{array}{l}-0.3690 * * * \\
(0.1219)\end{array}$ & $\begin{array}{l}-0.2675 \\
(0.1864) \\
\end{array}$ & $\begin{array}{l}-0.1386 \\
(0.1066)\end{array}$ & $\begin{array}{l}-0.2608 * * * \\
(0.0958)\end{array}$ & $\begin{array}{l}-0.1743^{*} \\
(0.1008) \\
\end{array}$ & $\begin{array}{l}-0.2556 * * * \\
(0.0982) \\
\end{array}$ \\
\hline Index of technology & $\begin{array}{l}-0.0604 * * \\
(0.0286)\end{array}$ & $\begin{array}{l}-0.0538 \\
(0.0454)\end{array}$ & $\begin{array}{l}-0.0444 \\
(0.0301)\end{array}$ & $\begin{array}{l}-0.1074 * * * \\
(0.0245)\end{array}$ & $\begin{array}{l}-0.0437^{*} \\
(0.0265)\end{array}$ & $\begin{array}{l}-0.1057^{* * *} \\
(0.0250)\end{array}$ \\
\hline Single establishment firm & $\begin{array}{l}-0.0511 \\
(0.0546) \\
\end{array}$ & $\begin{array}{l}-0.0138 \\
(0.0912)\end{array}$ & $\begin{array}{l}-0.1020^{*} \\
(0.0570)\end{array}$ & $\begin{array}{c}0.0018 \\
(0.0430)\end{array}$ & $\begin{array}{c}0.0781 \\
(0.0478) \\
\end{array}$ & $\begin{array}{l}-0.0055 \\
(0.0445) \\
\end{array}$ \\
\hline Publicly listed firm & $\begin{array}{c}0.0174 \\
(0.1486) \\
\end{array}$ & $\begin{array}{l}-0.2563 \\
(0.2018) \\
\end{array}$ & $\begin{array}{l}-0.0302 \\
(0.1419) \\
\end{array}$ & $\begin{array}{l}-0.1993 * * * \\
(0.0563)\end{array}$ & $\begin{array}{l}-0.1580^{* *} \\
(0.0648) \\
\end{array}$ & $\begin{array}{l}-0.2095 * * * \\
(0.0571) \\
\end{array}$ \\
\hline $\begin{array}{l}\text { Constant + industry } \\
\text { dummies }\end{array}$ & Yes & Yes & $\begin{array}{l}\text { No industry } \\
\text { dummies }\end{array}$ & Yes & Yes & Yes \\
\hline \multicolumn{7}{|l|}{ Selection } \\
\hline Works council & & & $\begin{array}{l}-0.1216 \\
(0.2370) \\
\end{array}$ & & & $\begin{array}{l}-0.0801 \\
(0.1683) \\
\end{array}$ \\
\hline Wage & & & $\begin{array}{c}0.1893 \\
(0.2929)\end{array}$ & & & $\begin{array}{l}0.4367 * * * \\
(0.1321)\end{array}$ \\
\hline Establishment size & & & $\begin{array}{l}-0.1413 \\
(0.1989) \\
\end{array}$ & & & $\begin{array}{l}0.1881^{* * *} \\
(0.0470) \\
\end{array}$ \\
\hline $\begin{array}{l}\text { Share of part-time } \\
\text { employees }\end{array}$ & & & $\begin{array}{l}2.2591 * * \\
(0.8939)\end{array}$ & & & $\begin{array}{l}1.6039 * * \\
(0.4040)\end{array}$ \\
\hline $\begin{array}{l}\text { Share of female } \\
\text { employees }\end{array}$ & & & $\begin{array}{c}0.2220 \\
(0.4560) \\
\end{array}$ & & & $\begin{array}{c}0.1409 \\
(0.2679) \\
\end{array}$ \\
\hline Index of technology & & & $\begin{array}{l}-0.1326 \\
(0.1287) \\
\end{array}$ & & & $\begin{array}{c}0.0987 \\
(0.0703) \\
\end{array}$ \\
\hline Single establishment firm & & & $\begin{array}{c}0.0620 \\
(0.2557)\end{array}$ & & & $\begin{array}{l}0.2878 * * * \\
(0.1280)\end{array}$ \\
\hline Publicly listed firm & & & $\begin{array}{l}-0.4122 \\
(0.5083)\end{array}$ & & & $\begin{array}{c}0.0102 \\
(0.1805) \\
\end{array}$ \\
\hline $\begin{array}{l}\text { Share of fixed-term } \\
\text { contract workers }\end{array}$ & & & $\begin{array}{l}-1.8851^{*} \\
(1.0549)\end{array}$ & & & $\begin{array}{l}-1.298 * * \\
(0.6054)\end{array}$ \\
\hline $\begin{array}{l}\text { Constant + industry } \\
\text { dummies }\end{array}$ & & & $\begin{array}{c}\text { No industry } \\
\text { dummies }\end{array}$ & & & Yes \\
\hline Adjusted $\mathrm{R}^{2}$ & 0.58 & 0.19 & & 0.12 & 0.07 & \\
\hline $\mathrm{F}$ & 16.39 & 4.44 & & 7.09 & 5.73 & \\
\hline$\rho$ & & & $\begin{array}{l}-0.3931 \\
(0.3078) \\
\end{array}$ & & & $\begin{array}{l}-0.0889 \\
(0.1734) \\
\end{array}$ \\
\hline $\operatorname{LR}\left[\chi^{2}(1)\right]$ & & & $0.99[0.3206]$ & & & $0.20[0.6584]$ \\
\hline Wald $\chi^{2}$ & & & 188.61 & & & 95.71 \\
\hline $\begin{array}{l}\text { Surviving } \\
\text { Non-surviving establishments }\end{array}$ & 143 & 197 & $\begin{array}{c}131 \\
52\end{array}$ & 600 & 784 & $\begin{array}{l}561 \\
174\end{array}$ \\
\hline
\end{tabular}

Notes: See models (3) and (4) in the text. They were implemented using the growth rate formula: $g_{i} \equiv\left(l_{i t}-l_{i t-j}\right) / l_{i t-j}$. LR is the likelihood ratio test on the independence of the outcome and selection models. The selection model was implemented using STATA's one-step maximum likelihood procedure. Industry dummies in column (3) were dropped to achieve a quicker convergence of the model. 
TABLE 5

EMPLOYMENT DETERMINATION BASED ON A DYNAMIC LABOR DEMAND MODEL GIVING WORKS COUNCIL EFFECTS ON BOTH THE SPEED OF EMPLOYMENT ADJUSTMENT AND EMPLOYMENT GROWTH

\begin{tabular}{|c|c|c|c|c|}
\hline \multirow{3}{*}{ Variable } & \multicolumn{4}{|c|}{ Establishment size } \\
\hline & \multicolumn{2}{|c|}{ 21-100 employees } & \multicolumn{2}{|c|}{$\begin{array}{c}\text { All establishments } \\
\text { ( } \geq 5 \text { employees) }\end{array}$} \\
\hline & (1) & (2) & (3) & $(4)$ \\
\hline$l_{\text {it-1 }}$ & $\begin{array}{c}0.9861 * * * \\
(0.0503)\end{array}$ & $\begin{array}{c}0.9840 * * * \\
(0.0495)\end{array}$ & $\begin{array}{c}0.9933 * * * \\
(0.0300)\end{array}$ & $\begin{array}{c}0.9838 * * * \\
(0.0261)\end{array}$ \\
\hline Wage $_{\text {it }}$ & $\begin{array}{c}-0.1164 * * \\
(0.0505) \\
\end{array}$ & $\begin{array}{c}-0.1164 * * \\
(0.0503)\end{array}$ & $\begin{array}{l}-0.0846 \\
(0.0612) \\
\end{array}$ & $\begin{array}{l}-0.0885 \\
(0.0617) \\
\end{array}$ \\
\hline Wage $_{\text {it-1 }}$ & $\begin{array}{c}0.0667 \\
(0.0491)\end{array}$ & $\begin{array}{c}0.0668 \\
(0.0494)\end{array}$ & $\begin{array}{c}0.0546 \\
(0.0356)\end{array}$ & $\begin{array}{c}0.0562 \\
(0.0351)\end{array}$ \\
\hline Price of intermediate input ${ }_{\text {it }}$ & $\begin{array}{c}0.0125 \\
(0.0126) \\
\end{array}$ & $\begin{array}{c}0.0122 \\
(0.0124) \\
\end{array}$ & $\begin{array}{l}-0.0035 \\
(0.0148) \\
\end{array}$ & $\begin{array}{l}-0.0032 \\
(0.0138) \\
\end{array}$ \\
\hline Capital $_{\text {it }}$ & $\begin{array}{c}-0.0108 \\
(0.0093)\end{array}$ & $\begin{array}{l}-0.0106 \\
(0.0092)\end{array}$ & $\begin{array}{c}0.0064 \\
(0.0128)\end{array}$ & $\begin{array}{c}0.0067 \\
(0.0125)\end{array}$ \\
\hline Shock $_{\text {it }}$ & $\begin{array}{c}0.1188 * * * \\
(0.0387) \\
\end{array}$ & $\begin{array}{c}0.1186 * * * \\
(0.0388) \\
\end{array}$ & $\begin{array}{c}0.0780 * * * \\
(0.0272) \\
\end{array}$ & $\begin{array}{c}0.0778 * * * \\
(0.0272) \\
\end{array}$ \\
\hline $\mathrm{l}_{\mathrm{it}-1} *$ Works council $_{\mathrm{it}}{ }^{\mathrm{a}}$ & $\begin{array}{l}-0.0064 \\
(0.0085)\end{array}$ & - & $\begin{array}{l}-0.0131 \\
(0.0146\end{array}$ & - \\
\hline Works council $_{\text {it }} * \mathrm{t}^{\mathrm{b}}$ & - & $\begin{array}{l}-0.000013 \\
(0.000016\end{array}$ & - & $\begin{array}{c}-0.000023 \\
(0.000036)\end{array}$ \\
\hline Constant + time dummies & Yes & Yes & Yes & Yes \\
\hline Wald & $633.3^{* * *}$ & $638.7 * * *$ & $16490 * * *$ & $16180 * * *$ \\
\hline $\mathrm{m}_{1}$ & $-4.46^{* * *}$ & $-3.93^{* * *}$ & $-4.11^{* * *}$ & $-4.11^{* * *}$ \\
\hline $\mathrm{m}_{2}$ & 0.36 & 0.36 & 0.36 & 0.34 \\
\hline Sargan & 86.05 & 85.87 & 74.71 & 75.57 \\
\hline Number of observations & 678 & 678 & 2902 & 2902 \\
\hline Number of establishments & 134 & 134 & 542 & 542 \\
\hline
\end{tabular}

Notes: Model specifications in columns (1) and (3) are given by equation (5'), while columns (2) and (4) are given by equation (7), and were estimated using the GMM-SYS method (one-step) (see text.) The number of observations is given by $O=\sum_{i} T_{i}$, where the maximum (useable) length of the time-series is 7 years, 1995-2001. Asymptotic standard errors robust to general cross-section and time-series heteroskedasticity are given in parentheses; Wald is a test of joint significance of the independent variables; $m_{1}$ and $m_{2}$ are tests for first- and second-order serial correlation in the first-differenced residuals; and Sargan is a test of overidentifying restrictions. The instruments used are: $l_{i t-2}, l_{i t-3}, \ldots, l_{i 1} ; w_{i t-2} ; p_{i t-1}$, and $k_{i t-1}$ for the differenced equations, and $\Delta l_{i t-1}, \Delta w_{i t-1}, \Delta p_{i t-1}, \Delta k_{i t-1}$ for the levels equations. $w$ denotes the wage level, $p$ the price of the intermediate input, and $k$ the capital stock; the shock variable is defined as the first difference of (log) output demand, and $p$ is given by intermediate input divided by total employment. In the estimation, we have used the DPD 1.2 software for OX, version 3.30, available at http://www.nuff.ox.ac.uk/Users/Doornik.

a denotes works council effect on the speed of employment adjustment.

${ }^{\mathrm{b}}$ denotes works council effect on employment growth. 
APPENDIX TABLE 1

DETERMINANTS OF THE CHANGE IN EMPLOYMENT, 1993-2001, WITH ATTRITIONS AND CONTROLLING FOR COLLECTIVE AGREEMENT COVERAGE

\begin{tabular}{|c|c|c|c|c|}
\hline \multirow{3}{*}{ Variable } & \multicolumn{4}{|c|}{ Establishment size } \\
\hline & \multicolumn{2}{|c|}{ 21-100 employees } & \multicolumn{2}{|c|}{$\begin{array}{c}\text { All establishments } \\
\text { ( } \geq 5 \text { employees) }\end{array}$} \\
\hline & $(1)$ & $(2)$ & (3) & $(4)$ \\
\hline Works council & $\begin{array}{l}-0.1682^{*} \\
(0.0916)\end{array}$ & $\begin{array}{l}-0.0341^{* *} \\
(0.0161)\end{array}$ & $\begin{array}{l}-0.1799 * * * \\
(0.0564)\end{array}$ & $\begin{array}{l}-0.0287 * * * \\
(0.0093)\end{array}$ \\
\hline Collective agreement & $\begin{array}{c}0.0459 \\
(0.0589)\end{array}$ & $\begin{array}{c}0.0035 \\
(0.0103)\end{array}$ & $\begin{array}{c}0.0459 \\
(0.0417)\end{array}$ & $\begin{array}{c}0.0053 \\
(0.0068)\end{array}$ \\
\hline $\begin{array}{l}\text { Collective agreement*works } \\
\text { council }\end{array}$ & $\begin{array}{l}-0.0646 \\
(0.1067)\end{array}$ & $\begin{array}{l}0.0026 \\
(0.0187)\end{array}$ & $\begin{array}{l}-0.1071^{*} \\
(0.0585)\end{array}$ & $\begin{array}{l}-0.0172 * \\
(0.0096)\end{array}$ \\
\hline Wage & $\begin{array}{l}-0.0510 \\
(0.0694)\end{array}$ & $\begin{array}{l}-0.0021 \\
(0.0122)\end{array}$ & $\begin{array}{l}-0.1382 * * * \\
(0.0349)\end{array}$ & $\begin{array}{l}-0.0202 * * * \\
(0.0057)\end{array}$ \\
\hline Establishment size & $\begin{array}{l}0.4055^{* * *} \\
(0.0388) \\
\end{array}$ & $\begin{array}{l}0.0497 * * * \\
(0.0068) \\
\end{array}$ & $\begin{array}{l}0.0958 * * * \\
(0.0107) \\
\end{array}$ & $\begin{array}{l}0.0154^{* * *} \\
(0.0017) \\
\end{array}$ \\
\hline Share of part-time employees & $\begin{array}{c}0.2415 \\
(0.1509) \\
\end{array}$ & $\begin{array}{c}0.0195 \\
(0.0265) \\
\end{array}$ & $\begin{array}{r}0.1775^{*} \\
(0.0963) \\
\end{array}$ & $\begin{array}{l}0.0341^{* *} \\
(0.0158) \\
\end{array}$ \\
\hline Share of female employees & $\begin{array}{l}-0.1643 \\
(0.1119)\end{array}$ & $\begin{array}{l}-0.0112 \\
(0.0196)\end{array}$ & $\begin{array}{l}-0.2011 * * * \\
(0.0633)\end{array}$ & $\begin{array}{l}-0.0319 * * * \\
(0.0104)\end{array}$ \\
\hline Index of technology & $\begin{array}{l}-0.0779 * * * \\
(0.0273)\end{array}$ & $\begin{array}{l}-0.0136 * * * \\
(0.0048)\end{array}$ & $\begin{array}{l}-0.0896 * * * \\
(0.0165)\end{array}$ & $\begin{array}{l}-0.0142 * * * \\
(0.0027)\end{array}$ \\
\hline Single establishment firm & $\begin{array}{l}0.0360 \\
(0.0542)\end{array}$ & $\begin{array}{l}0.0068 \\
(0.0095)\end{array}$ & $\begin{array}{c}0.0077 \\
(0.0280)\end{array}$ & $\begin{array}{c}0.0011 \\
(0.0046)\end{array}$ \\
\hline Publicly listed firm & $\begin{array}{l}0.4086 * * * \\
(0.1231)\end{array}$ & $\begin{array}{l}0.0591^{* * *} \\
(0.0216) \\
\end{array}$ & $\begin{array}{l}-0.1380 * * * \\
(0.0359)\end{array}$ & $\begin{array}{l}-0.0224^{* * *} \\
(0.0059)\end{array}$ \\
\hline Constant + industry dummies & Yes & & Yes & \\
\hline Adjusted $\mathrm{R}^{2}$ & 0.38 & 0.24 & 0.15 & 0.15 \\
\hline $\mathrm{F}$ & 10.59 & 5.76 & 13.96 & 13.44 \\
\hline $\begin{array}{l}\mathrm{N} \text { (surviving establishments, } \\
\text { plus attritions) }\end{array}$ & 232 & 232 & 1105 & 1105 \\
\hline
\end{tabular}

Notes: See Table 3. 
APPENDIX TABLE 2

DETERMINANTS OF THE CHANGE IN EMPLOYMENT, 1993-2001, CONTROLLING FOR POTENTIAL SURVIVAL BIAS AND COLLECTIVE AGREEMENT COVERAGE

\begin{tabular}{|c|c|c|c|c|c|c|}
\hline & \multicolumn{6}{|c|}{ Establishment size } \\
\hline & \multicolumn{3}{|c|}{ 21-100 Employees } & \multicolumn{3}{|c|}{ All Establishments ( $\geq 5$ employees) } \\
\hline & \multirow{2}{*}{$\begin{array}{c}\text { Unadjusted } \\
\text { for selection }\end{array}$} & \multicolumn{2}{|c|}{ Adjusted for selection } & \multirow{2}{*}{$\begin{array}{l}\text { Unadjusted } \\
\text { for selection }\end{array}$} & \multicolumn{2}{|c|}{ Adjusted for selection } \\
\hline & & $\begin{array}{c}\text { Closings }= \\
-100 \%\end{array}$ & $\begin{array}{l}\text { Full maximum- } \\
\text { likelihood }\end{array}$ & & $\begin{array}{c}\text { Closings=- } \\
100 \%\end{array}$ & $\begin{array}{l}\text { Full maximum- } \\
\text { likelihood }\end{array}$ \\
\hline Change in employment & $(1)$ & $(2)$ & (3) & (4) & $(5)$ & (6) \\
\hline Works council & $\begin{array}{l}-0.0953 \\
(0.0956)\end{array}$ & $\begin{array}{l}-0.1459 \\
(0.1482)\end{array}$ & $\begin{array}{l}-0.1973 * \\
(0.1018)\end{array}$ & $\begin{array}{l}-0.1446^{*} \\
(0.0864)\end{array}$ & $\begin{array}{l}-0.2274 * * \\
(0.0946)\end{array}$ & $\begin{array}{l}-0.1533^{*} \\
(0.0893)\end{array}$ \\
\hline Collective agreement & $\begin{array}{c}0.0611 \\
(0.0599) \\
\end{array}$ & $\begin{array}{c}0.0966 \\
(0.1013) \\
\end{array}$ & $\begin{array}{c}0.0589 \\
(0.0617) \\
\end{array}$ & $\begin{array}{l}0.1264 * * \\
(0.0598)\end{array}$ & $\begin{array}{c}0.1085^{*} \\
(0.0660) \\
\end{array}$ & $\begin{array}{c}0.1163^{*} \\
(0.0618) \\
\end{array}$ \\
\hline $\begin{array}{l}\text { Collective agreement*works } \\
\text { council }\end{array}$ & $\begin{array}{l}-0.1216 \\
(0.1110)\end{array}$ & $\begin{array}{l}-0.1682 \\
(0.1701)\end{array}$ & $\begin{array}{l}-0.0445 \\
(0.1138)\end{array}$ & $\begin{array}{l}-0.1671^{*} \\
(0.0885)\end{array}$ & $\begin{array}{l}-0.0351 \\
(0.0973)\end{array}$ & $\begin{array}{l}-0.1501^{*} \\
(0.0917)\end{array}$ \\
\hline Wage & $\begin{array}{l}-0.0589 \\
(0.0692)\end{array}$ & $\begin{array}{l}-0.0390 \\
(0.1088)\end{array}$ & $\begin{array}{l}-0.0332 \\
(0.0721) \\
\end{array}$ & $\begin{array}{l}-0.1325^{* * *} \\
(0.0480)\end{array}$ & $\begin{array}{c}0.0176 \\
(0.0512)\end{array}$ & $\begin{array}{l}-0.1757^{* * *} \\
(0.0505)\end{array}$ \\
\hline Establishment size & $\begin{array}{l}0.4451^{* * *} \\
(0.0366)\end{array}$ & $\begin{array}{l}0.3394 * * * \\
(0.0629)\end{array}$ & $\begin{array}{l}0.4933^{* * *} \\
(0.0408)\end{array}$ & $\begin{array}{l}0.0832^{* * *} \\
(0.0159)\end{array}$ & $\begin{array}{l}0.1098^{* * *} \\
(0.0178)\end{array}$ & $\begin{array}{l}0.0849 * * * \\
(0.0166)\end{array}$ \\
\hline $\begin{array}{l}\text { Share of part-time } \\
\text { employees }\end{array}$ & $\begin{array}{l}0.4542 * * * \\
(0.1576) \\
\end{array}$ & $\begin{array}{l}0.6098^{* *} \\
(0.2623) \\
\end{array}$ & $\begin{array}{c}0.2519 \\
(0.1612) \\
\end{array}$ & $\begin{array}{l}0.3724 * * * \\
(0.1404)\end{array}$ & $\begin{array}{l}0.6633^{* * * *} \\
(0.1507)\end{array}$ & $\begin{array}{c}0.3550 * * \\
(0.1482) \\
\end{array}$ \\
\hline Share of female employees & $\begin{array}{l}-0.3573^{* * * *} \\
(0.1237)\end{array}$ & $\begin{array}{l}-0.3966 * * \\
(0.1967) \\
\end{array}$ & $\begin{array}{l}-0.1197 \\
(0.1079)\end{array}$ & $\begin{array}{l}-0.2469 * \\
(0.0958)\end{array}$ & $\begin{array}{l}-0.1843^{*} \\
(0.1031) \\
\end{array}$ & $\begin{array}{l}-0.2468 * * \\
(0.0979)\end{array}$ \\
\hline Index of technology & $\begin{array}{l}-0.0608^{* *} \\
(0.0288)\end{array}$ & $\begin{array}{l}-0.0837 * \\
(0.0455)\end{array}$ & $\begin{array}{l}-0.0441 \\
(0.0305)\end{array}$ & $\begin{array}{l}-0.1083^{* * *} \\
(0.0245)\end{array}$ & $\begin{array}{l}-0.0689 * * \\
(0.0269)\end{array}$ & $\begin{array}{l}-0.1058^{* * *} \\
(0.0249)\end{array}$ \\
\hline Single establishment firm & $\begin{array}{l}-0.0398 \\
(0.0560)\end{array}$ & $\begin{array}{c}0.0159 \\
(0.0907) \\
\end{array}$ & $\begin{array}{l}-0.0938^{*} \\
(0.0578) \\
\end{array}$ & $\begin{array}{c}0.0049 \\
(0.0432) \\
\end{array}$ & $\begin{array}{c}0.0665 \\
(0.0480)\end{array}$ & $\begin{array}{l}-0.0015 \\
(0.0443) \\
\end{array}$ \\
\hline Publicly listed firm & $\begin{array}{c}0.0381 \\
(0.1503)\end{array}$ & $\begin{array}{l}-0.1650 \\
(0.2069)\end{array}$ & $\begin{array}{l}-0.0381 \\
(0.1423)\end{array}$ & $\begin{array}{l}-0.1943^{* * *} \\
(0.0562)\end{array}$ & $\begin{array}{l}-0.1695^{* * *} \\
(0.0648)\end{array}$ & $\begin{array}{l}-0.2056^{* * *} \\
(0.0569)\end{array}$ \\
\hline $\begin{array}{l}\text { Constant + industry } \\
\text { dummies }\end{array}$ & Yes & Yes & $\begin{array}{c}\text { No industry } \\
\text { dummies }\end{array}$ & Yes & Yes & Yes \\
\hline \multicolumn{7}{|l|}{ Selection } \\
\hline Works council & & & $\begin{array}{l}-0.3343 \\
(0.4216) \\
\end{array}$ & & & $\begin{array}{l}-0.3252 \\
(0.2581) \\
\end{array}$ \\
\hline Collective agreement & & & $\begin{array}{c}0.1972 \\
(0.3239)\end{array}$ & & & $\begin{array}{c}0.2386 \\
(0.1850)\end{array}$ \\
\hline $\begin{array}{l}\text { Collective agreement*works } \\
\text { council }\end{array}$ & & & $\begin{array}{c}0.0689 \\
(0.4862) \\
\end{array}$ & & & $\begin{array}{c}0.3394 \\
(0.2664) \\
\end{array}$ \\
\hline Wage & & & $\begin{array}{c}0.1950 \\
(0.3346)\end{array}$ & & & $\begin{array}{l}0.4936^{* * * *} \\
(0.1441)\end{array}$ \\
\hline Establishment size & & & $\begin{array}{l}-0.2320 \\
(0.2137)\end{array}$ & & & $\begin{array}{l}0.1623^{* * *} \\
(0.0528)\end{array}$ \\
\hline $\begin{array}{l}\text { Share of part-time } \\
\text { employees }\end{array}$ & & & $\begin{array}{l}1.3744 \\
(0.8897)\end{array}$ & & & $\begin{array}{l}1.555^{* * *} \\
(0.4490)\end{array}$ \\
\hline Share of female employees & & & $\begin{array}{c}0.4170 \\
(0.5225)\end{array}$ & & & $\begin{array}{c}0.1682 \\
(0.2952)\end{array}$ \\
\hline Index of technology & & & $\begin{array}{l}-0.2115 \\
(0.1410)\end{array}$ & & & $\begin{array}{c}0.0276 \\
(0.0775)\end{array}$ \\
\hline Single establishment firm & & & $\begin{array}{c}0.1556 \\
(0.2738)\end{array}$ & & & $\begin{array}{c}0.2669 * \\
(0.1405)\end{array}$ \\
\hline Publicly listed firm & & & $\begin{array}{l}-0.2975 \\
(0.5557)\end{array}$ & & & $\begin{array}{l}-0.0396 \\
(0.1985)\end{array}$ \\
\hline $\begin{array}{l}\text { Share of fixed-term contract } \\
\text { workers }\end{array}$ & & & $\begin{array}{l}-2.1079 * \\
(1.0850)\end{array}$ & & & $\begin{array}{l}-1.5202 * * \\
(0.6532)\end{array}$ \\
\hline $\begin{array}{l}\text { Constant and industry } \\
\text { dummies }\end{array}$ & & & $\begin{array}{c}\text { No industry } \\
\text { dummies }\end{array}$ & & & Yes \\
\hline Adjusted $\mathrm{R}^{2}$ & 0.58 & 0.20 & & 0.12 & 0.07 & \\
\hline $\mathrm{F}$ & 14.24 & 4.09 & & 6.51 & 4.92 & \\
\hline$\rho$ & & & $-0.3957(0.327)$ & & & $-0.0936(0.166)$ \\
\hline $\operatorname{LR}\left[\chi^{2}(1)\right]$ & & & $0.95[0.3304]$ & & & $0.23[0.6287]$ \\
\hline Wald $\chi^{2}$ & & & 189.54 & & & 100.27 \\
\hline $\begin{array}{l}\text { Surviving } \\
\text { Non-surviving establishments }\end{array}$ & 143 & 185 & $\begin{array}{c}131 \\
40\end{array}$ & 600 & 738 & $\begin{array}{l}561 \\
129\end{array}$ \\
\hline
\end{tabular}

Notes: See Table 4. 


\section{ESTUDOS DO G.E.M.F.}

(Available on-line at http://gemf.fe.uc.pt)

2005-07 Firm Growth and Liquidity Constraints: A Dynamic Analysis

- Blandina Oliveira \& Adelino Fortunato

2005-06 The Effect of Works Councils on Employment Change

- John T. Addison \& Paulino Teixeira

2005-05 Le Rôle de la Consommation Publique dans la Croissance: le cas de I'Union Européenne - João Sousa Andrade, Maria Adelaide Silva Duarte \& Claude Berthomieu

2005-04 The Dynamics of the Growth of Firms: Evidence from the Services Sector - Blandina Oliveira \& Adelino Fortunato

2005-03 The Determinants of Firm Performance: Unions, Works Councils, and Employee Involvement/High Performance Work Practices

- John T. Addison

2005-02 Has the Stability and Growth Pact stabilised? Evidence from a panel of 12 European countries and some implications for the reform of the Pact

- Carlos Fonseca Marinheiro

2005-01 Sustainability of Portuguese Fiscal Policy in Historical Perspective - Carlos Fonseca Marinheiro

2004-03 Human capital, mechanisms of technological diffusion and the role of technological shocks in the speed of diffusion. Evidence from a panel of Mediterranean countries

- Maria Adelaide Duarte \& Marta Simões

2004-02 What Have We Learned About The Employment Effects of Severance Pay? Further Iterations of Lazear et al.

- John T. Addison \& Paulino Teixeira

2004-01 How the Gold Standard Functioned in Portugal: an analysis of some macroeconomic aspects - António Portugal Duarte \& João Sousa Andrade

2003-07 Testing Gibrat's Law: Empirical Evidence from a Panel of Portuguese Manufacturing Firms - Blandina Oliveira \& Adelino Fortunato

2003-06 Régimes Monétaires et Théorie Quantitative du Produit Nominal au Portugal (1854-1998) - João Sousa Andrade

2003-05 Causas do Atraso na Estabilização da Inflação: Abordagem Teórica e Empírica - Vítor Castro

2003-04 The Effects of Households' and Firms' Borrowing Constraints on Economic Growth - Maria da Conceição Costa Pereira

2003-03 Second Order Filter Distribution Approximations for Financial Time Series with Extreme Outliers

- J. Q. Smith \& António A. F. Santos

2003-02 Output Smoothing in EMU and OECD: Can We Forego Government Contribution? A risk sharing approach

- Carlos Fonseca Marinheiro

2003-01 Um modelo VAR para uma Avaliação Macroeconómica de Efeitos da Integração Europeia da Economia Portuguesa

- João Sousa Andrade 
2002-08 Discrimination des facteurs potentiels de croissance et type de convergence de l'économie portugaise dans l'UE à travers la spécification de la fonction de production macroéconomique. Une étude appliquée de données de panel et de séries temporelles

- Marta Simões \& Maria Adelaide Duarte

2002-07 Privatisation in Portugal: employee owners or just happy employees? -Luís Moura Ramos \& Rita Martins

2002-06 The Portuguese Money Market: An analysis of the daily session - Fátima Teresa Sol Murta

2002-05 As teorias de ciclo políticos e o caso português - Rodrigo Martins

2002-04 Fundos de aç̧ões internacionais: uma avaliação de desempenho - Nuno M. Silva

2002-03 The consistency of optimal policy rules in stochastic rational expectations models - David Backus \& John Driffill

2002-02 The term structure of the spreads between Portuguese and German interest rates during stage II of EMU

- José Soares da Fonseca

2002-01 O processo desinflacionista português: análise de alguns custos e benefícios

- António Portugal Duarte

2001-14 Equity prices and monetary policy: an overview with an exploratory model

- Fernando Alexandre \& Pedro Bação

2001-13 A convergência das taxas de juro portuguesas para os níveis europeus durante a segunda metade da década de noventa

- José Soares da Fonseca

2001-12 Le rôle de l'investissement dans l'éducation sur la croissance selon différentes spécifications du capital humain.

- Adelaide Duarte \& Marta Simões

2001-11 Ricardian Equivalence: An Empirical Application to the Portuguese Economy

- Carlos Fonseca Marinheiro

2001-10 A Especificação da Função de Produção Macro-Económica em Estudos de Crescimento Económico.

- Maria Adelaide Duarte e Marta Simões

2001-09 Eficácia da Análise Técnica no Mercado Accionista Português

- Nuno Silva

2001-08 The Risk Premiums in the Portuguese Treasury Bills Interest Rates: Estimation by a cointegration method

- José Soares da Fonseca

2001-07 Principais factores de crescimento da economia portuguesa no espaço europeu

- Maria Adelaide Duarte e Marta Simões

2001-06 Inflation Targeting and Exchange Rate Co-ordination

- Fernando Alexandre, John Driffill e Fabio Spagnolo

2001-05 Labour Market Transition in Portugal, Spain, and Poland: A Comparative Perspective - Paulino Teixeira

2001-04 Paridade do Poder de Compra e das Taxas de Juro: Um estudo aplicado a três países da UEM

- António Portugal Duarte 
2001-03 Technology, Employment and Wages

- John T. Addison \& Paulino Teixeira

2001-02 Human capital investment through education and economic growth. A panel data analysis based on a group of Latin American countries

- Maria Adelaide Duarte \& Marta Simões

2001-01 Risk Premiums in the Porutguese Treasury Bills Interest Rates from 1990 to 1998. An ARCH-M Approach

- José Soares da Fonseca

2000-08 Identificação de Vectores de Cointegração: Análise de Alguns Exemplos

- Pedro Miguel Avelino Bação

2000-07 Imunização e M-quadrado: Que relação?

- Jorge Cunha

2000-06 Eficiência Informacional nos Futuros Lisbor 3M

- Nuno M. Silva

2000-05 Estimation of Default Probabilities Using Incomplete Contracts Data

- J. Santos Silva \& J. Murteira

2000-04 Un Essaie d'Application de la Théorie Quantitative de la Monnaie à l'économie portugaise, 1854-1998

- João Sousa Andrade

2000-03 Le Taux de Chômage Naturel comme un Indicateur de Politique Economique? Une application à l'économie portugaise

- Adelaide Duarte \& João Sousa Andrade

2000-02 La Convergence Réelle Selon la Théorie de la Croissance: Quelles Explications pour I'Union Européenne?

- Marta Cristina Nunes Simões

2000-01 Política de Estabilização e Independência dos Bancos Centrais

- João Sousa Andrade

1999-09 Nota sobre a Estimação de Vectores de Cointegração com os Programas CATS in RATS, PCFIML E EVIEWS

- Pedro Miguel Avelino Bação

1999-08 A Abertura do Mercado de Telecomunicações Celulares ao Terceiro Operador: Uma Decisão Racional?

- Carlos Carreira

1999-07 Is Portugal Really so Arteriosclerotic? Results from a Cross-Country Analysis of Labour Adjustment

- John T. Addison \& Paulino Teixeira

1999-06 The Effect of Dismissals Protection on Employment: More on a Vexed Theme - John T. Addison, Paulino Teixeira e Jean-Luc Grosso

1999-05 A Cobertura Estática e Dinâmica através do Contrato de Futuros PSI-20. Estimação das Rácios e Eficácia Ex Post e Ex Ante

- Helder Miguel C. V. Sebastião

1999-04 Mobilização de Poupança, Financiamento e Internacionalização de Carteiras - João Sousa Andrade

1999-03 Natural Resources and Environment

- Adelaide Duarte 
1999-02 L'Analyse Positive de la Politique Monétaire

- Chistian Aubin

1999-01 Economias de Escala e de Gama nos Hospitais Públicos Portugueses: Uma Aplicação da Função de Custo Variável Translog

- Carlos Carreira

1998-11 Equilíbrio Monetário no Longo e Curto Prazos - Uma Aplicação à Economia Portuguesa - João Sousa Andrade

1998-10 Algumas Observações Sobre o Método da Economia

- João Sousa Andrade

1998-09 Mudança Tecnológica na Indústria Transformadora: Que Tipo de Viés Afinal?

- Paulino Teixeira

1998-08 Portfolio Insurance and Bond Management in a Vasicek's Term Structure of Interest Rates - José Alberto Soares da Fonseca

1998-07 Financial Innovation and Money Demand in Portugal: A Preliminary Study

- Pedro Miguel Avelino Bação

1998-06 The Stability Pact and Portuguese Fiscal Policy: the Application of a VAR Model

- Carlos Fonseca Marinheiro

1998-05 A Moeda Única e o Processo de Difusão da Base Monetária

- José Alberto Soares da Fonseca

1998-04 La Structure par Termes et la Volatilité des Taux d'intérêt LISBOR

- José Alberto Soares da Fonseca

1998-03 Regras de Comportamento e Reformas Monetárias no Novo SMI

- João Sousa Andrade

1998-02 Um Estudo da Flexibilidade dos Salários: o Caso Espanhol e Português

- Adelaide Duarte e João Sousa Andrade

1998-01 Moeda Única e Internacionalização: Apresentação do Tema

- João Sousa Andrade

1997-09 Inovação e Aplicações Financeiras em Portugal

- Pedro Miguel Avelino Bação

1997-08 Estudo do Efeito Liquidez Aplicado à Economia Portuguesa

- João Sousa Andrade

1997-07 An Introduction to Conditional Expectations and Stationarity

- Rui Manuel de Almeida

1997-06 Definição de Moeda e Efeito Berlusconi

- João Sousa Andrade

1997-05 A Estimação do Risco na Escolha dos Portafólios: Uma Visão Selectiva

- António Alberto Ferreira dos Santos

1997-04 A Previsão Não Paramétrica de Taxas de Rentabilidade

- Pedro Manuel Cortesão Godinho

1997-03 Propriedades Assimptóticas de Densidades

- Rui Manuel de Almeida

1997-02 Co-Integration and VAR Analysis of the Term Structure of Interest Rates: an empirical study of the Portuguese money and bond markets

-João Sousa Andrade \& José Soares da Fonseca 
1997-01 Repartição e Capitalização. Duas Modalidades Complementares de Financiamento das Reformas

- Maria Clara Murteira

1996-08 A Crise e o Ressurgimento do Sistema Monetário Europeu - Luis Manuel de Aguiar Dias

1996-07 Housing Shortage and Housing Investment in Portugal a Preliminary View - Vítor Neves

1996-06 Housing, Mortgage Finance and the British Economy

- Kenneth Gibb \& Nile Istephan

1996-05 The Social Policy of The European Community, Reporting Information to Employees, a U.K. perspective: Historical Analysis and Prognosis

- Ken Shackleton

1996-04 O Teorema da Equivalência Ricardiana: aplicação à economia portuguesa - Carlos Fonseca Marinheiro

1996-03 O Teorema da Equivalência Ricardiana: discussão teórica - Carlos Fonseca Marinheiro

1996-02 As taxas de juro no MMl e a Restrição das Reservas Obrigatórias dos Bancos - Fátima Assunção Sol e José Alberto Soares da Fonseca

1996-01 Uma Análise de Curto Prazo do Consumo, do Produto e dos Salários - João Sousa Andrade 